\title{
RELASI KEKUASAAN KOMISI YUDISIAL-DEWAN PERWAKILAN RAKYAT DAN PRESIDEN DALAM PENGANGKATAN HAKIM AGUNG
}

Oleh:

\author{
Idul Rishan
}

\begin{abstract}
This research aim to answer 2 (two) problems in accordance to relation of authority of Judicial Commision-House of Representative and President in promoting supreme judges. First, this article analyze model of relation of authority between Judicial Commision-House of Representative and President in promoting supreme judges in Indonesia. Second, the article analyze implication of Constitutional Court's Verdict Number 27/PUU-XI/2013 to relation of authority between Judicial Commision-House of Representative and President in promoting supreme judges in Indonesia.

This article is using qualitative descriptive method. Type of research is normative juridical by exercising library research on study of positive law and nature of prescriptive.

This article conclude that (1), basically, relation of authoritybetween Judicial CommisionHouse of Representative and President designed to create check and balance principle in promoting supreme judges. Existency and involvement of Judicial Commision in democratic transition was expected as an answer and ending of bitter history in previous mechanism in promoting supreme judges which loaded with intervention of rulers. That expectation was not propotional when integrated to level of statute. Friction of paradigm occurred when House Representative expropriate the role as main actor in promoting supreme judge and negate the roles of Judicial Commision to relation of Authority which based on ratio. This friction triggered by accidental amandement of constitution, which evoke strong wave of reformation and the effort in preserving back classic model. (2), after the verdict of Constitutional Court issued, there are logic consequence to relation of Authority between Judicial CommisionHouse of Representative and Presidentin promoting supreme judges. Legally, it caused to inconstitutionality of ratio-based relation of authority. It also cause adisapovowal of fit and proper test of House of Representative, productivity of Supreme Court and inefficiency of budget. An idea to improve should be taken by creating corporate culture, changing flow of supervision of House of Representative and emerging mutual trust between involved organs in relation to promote supreme judges. That idea intended to transform inconstitutionality of "rasio-based" relation of authority into "trust-based" relation of authority.
\end{abstract}

\section{Keywords: Authority relation of Judicial Commision-House of Representative and} President, Promotion of Supreme Judges. 


\section{PENDAHULUAN}

Salah satu hajat korup kaum elit di era orde baru yang masih kental dalam ingatan yaitu besarnya intervensi eksekutif terhadap proses seleksi dan pengangkatan hakim agung. Pada era tersebut, proses seleksi dan pengangkatan hakim agung tidak dilaksanakan secara fair, transparan, dan independen.

Pentingnya proses seleksi yang transparan dan independen terhadap hakim agung, pada prinsipnya bertujuan untuk menghasilkan hakim agung yang kompeten dan berintegritas tinggi. Lebih dari pada itu proses seleksi dan pengangkatan hakim yang transparan dan independen dapat mencegah masuknya kepentingan politik dalam pemilihan hakim agung.

Hakim agung memegang peran yang sentral dalam proses peradilan. Hanya hakim yang baik yang diharapkan memutus perkara yang mencerminkan rasa keadilan masyarakat sesuai dengan hukum. Posisi strategis seorang hakim agung menjadi salah satu celah dalam memuluskan segala kebijakan para kaum elit penguasa. Di beberapa negara proses pemilihan hakim agung biasanya akan dipengaruhi oleh kepentingan politik. Seperti Christopher E. Smith menyatakan bahwa, Presiden cenderung mempunyai tujuan politik tertentu ketika menominasikan calon tertentu untuk menjadi hakim agung. Umumnya, presiden akan menominasikan seseorang yang mempunyai latar belakang ideologi dan preferensi kebijakan yang sama dengannya. ${ }^{1}$ Tidak heran jika hakim yang

1 Oce Madril, "Perbandingan Komisi Yudisial Di Asia”, Bunga Rampai Komisi Yudisial; Membumikan Tekad Menuju Peradilan Bersih, Jakarta: Sekjend KYRI, 2011, hlm. 336. baik hanya dapat lahir melalui sistem yang baik.

Tesis ini pun ibarat menjadi sebuah pembenaran dengan praktik yang terjadi di era orde baru. Sebastian Pompe misalnya, secara terang-terangan membuka sejarah kelam independensi peradilan di Indonesia dalam disertasinya yang berjudul The Indonesian Superme Court; A Study of Institutional Collapse. Terungkap pada masa-masa orde baru, Soeharto dengan mudahnya melanggengkan kooptasi politiknya terhadap pengangkatan hakim agung, sampai jabatan ketua Mahkamah Agung. ${ }^{2}$

Menjadi pengalaman yang begitu pahit terhadap independensi peradilan. Pasca lengsernya Soeharto yang identik dengan rezim otoritariannya, membawa secercah harapan baru akan reformasi konstitusi. Warisan relasi kekuasaan orde baru yang sarat dengan executive heavy, perlahanlahan resmi ditanggalkan seiring dengan amandemen konstitusi. Ketatanegaraan Indonesia menampilkan wajah baru setelah mengalami empat kali perubahan UUDN 1945, yang secara berantai dilakukan oleh MPR selama 4 tahun, sejak 1999 sampai 2002. Pembenahan dan penyempurnaan pun dilakukan dalam berbagai sektor, baik itu kekuasaan eksekutif, legislatif maupun yudikatif. Perubahan berantai di era transisi tersebut relatif mampu menyelesaikan ketatanegaraan yang lebih baik. ${ }^{3}$

\footnotetext{
2 Sebastian Pompe, Runtuhnya Institusi Mahkamah Agung, Jakarta: Lembaga Kajian dan Advokasi Untuk Independensi Peradilan, 2012, hlm. 98 dan hlm. 165 .

${ }^{3}$ Denny Indrayana, Negara antara Ada dan Tiada; Reformasi Hukum Ketatanegaraan, Jakarta: Kompas, 2008, hlm. 263.
} 
Berangkat dari pemikiran Lord Acton, kewenangan besar riskan untuk disalahgunakan (power tends to corrupt), pola relasi kekuasaan kembali dirancang bangun demi mewujudkan kekuasaan yang saling mengawasi dan mengimbangi (checks and balances). Prinsip saling kontrol dan saling imbang antar kekuasaan maupun organ konstitusi, semata-mata dibangun sebagai benteng untuk menahan hajat korup para kaum elit negara.

Amandemen konstitusi hadir sebagai dasar untuk melakukan pembenahan. Salah satu di antaranya, pembenahan tentang mekanisme seleksi dan pengangkatan hakim agung. Hal ini yang kemudian yang menjadi raison de 'etre diaturnya kewenangan Komisi Yudisial dalam rumpun kekuasaan kehakiman, yang berfungsi sebagai supporting element terhadap organ utama kekuasaan kehakiman.

Dalam Bab IX Kekuasaan Kehakiman, Pasal 24A Ayat (3) UUDN 1945, menyatakan;

"Calon hakim agung diusulkan Komisi Yudisial kepada Dewan Perwakilan Rakyat untuk mendapatkan persetujuan dan selanjutnya ditetapkan sebagai hakim agung oleh Presiden. ${ }^{4}$,

Kemudian dalam Pasal 24B Ayat (1) menyatakan;

"Komisi Yudisial bersifat mandiri yang berwenang mengusulkan pengangkatan hakim agung dan mempunyai wewenang lain dalam rangka menjaga dan

4 Lihat Pasal 24A Ayat (3) UUDN Pasca Amandemen. menegakkan kehormatan, keluhuran martabat, serta perilaku hakim. ${ }^{5}$ "

Konsekuensi logis masing-masing kewenangan konstitusional tersebut, membuat alur relasi kekuasaan dari Komisi Yudisial, Dewan Perwakilan Rakyat dan Presiden (KY-DPR dan Presiden). Relasi tersebut dibangun berdasarkan prinsip checks and balances mulai dari proses seleksi sampai dengan pengagkatan hakim agung. Namun pada akhir tahun 2013, denyut konstitusionalitas proses seleksi dan pengangkatan hakim agung, kembali berdetak.

Mahkamah Konstitusi sebagai the guardian of constitution, melalui putusan No. 27/PUU-XI/2013, menyatakan bahwa Dewan Perwakilan Rakyat tidak lagi mempunyai kewenangan untuk melakukan fit and proper test dan memilih calon hakim agung yang diusulkan oleh Komisi Yudisial. ${ }^{6}$ Dalih putusan Mahkamah Konstitusi (MK) tersebut, praktis merubah pola relasi kekuasaan antara KY-DPR dan Presiden dalam proses seleksi dan pengangkatan hakim agung.

Perubahan pola relasi ini secara signifikan juga dapat berimplikasi secara yuridis maupun politis terhadap pengangkatan hakim agung di Indonesia. Terlebih, di pundak para justice seeker perubahan relasi kekuasaan KY-DPR dan Presiden pasca putusan MK, diharapkan menjadi momentum dalam mewujudkan independensi peradilan di Indonesia.

Berdasarkan latar belakang di atas, maka dirumuskan masalah yang akan dikaji yaitu

\footnotetext{
5 Lihat Pasal 24B Ayat (1) UUDN Pasca Amandemen.

${ }^{6}$ Lihat Putusan MK Nomor 27/PUU-XI/2013.
} 
bagaimana model relasi kekuasaan KY-DPR dan Presiden dalam pengangkatan hakim agung dan implikasinya pasca putusan MK No.27/PUU-XI/2013 terhadap relasi kekuasaan KY-DPR dan Presiden dalam pengangkatan hakim agung.

Metode penelitian yang dipakai dalam penelitian ini adalah metode penelitian kualitatif. Penelitian ini merupakan penelitian yuridis normatif yang merupakan penelitian pustaka tentang kajian hukum positif bersifat preskriptif. Pendekatan yang dipakai antara lain pendekatan peraturan per undang-undangan, pendekatan historis, dan pendekatan konseptual. Bahan yang digunakan dalam penelitian ini adalah bahan primer, sekunder dan tersier.

\section{PEMBAHASAN}

\section{Relasi Kekuasaan KY-DPR dan PRESIDEN}

Historical design mencatat bahwa terdapat proses pembahasan yang cukup panjang ketika merumuskan pola relasi kekuasaan antara Komisi Yudisial (KY), Dewan Perwakilan Rakyat (DPR), dan Presiden dalam proses pengangkatan hakim agung. Proses panjang ini melewati dua masa fase pembahasan. Pertama; diawali pada masa transisi demokrasi ketika amandemen konstitusi, dan Kedua; Integrasi melalui level undang-undang.

\section{Rancang Bangun di masa Transisi Demokrasi}

Pada masa transisi demokrasi, cikal bakal pola relasi ini hadir ketika pembahasan perubahan pertama UUD di tahun 1999. Tema utama yang menjadi sorotan adalah persoalan pembatasan kekuasaan presiden yang selama 32 tahun telah mendominasi bangunan sistem ketatanegaraan bangsa Indonesia. Pembenahan ini diupayakan untuk kembali mengurai benang kusut antara dominasi kekuasaan eksekutif terhadap yudikatif yang berimbas pada independensi peradilan.

Pada pembahasan masa perubahan pertama UUD 1945, beberapa topik utama yang menjadi kajian dalam masa pembahasan khususnya mengenai relasi kekuasaan dalam pengangkatan hakim agung, yaitu Harun Kamil dari Fraksi Utusan Golongan (F-UG). Dalam pendapatnya menyatakan agar hakim agung diangkat dan diberhentikan oleh Majelis Permusyawaratan Rakyat (MPR). Usulan tersebut didasarkan atas kenyataan bahwa pada saat itu hakim agung diangkat dan diberhentikan oleh Presiden atas usul Dewan Perwakilan Rakyat (DPR). ${ }^{7}$

Model relasi seperti ini kembali dievaluasi karena mengindikasikan kuat bahwa, pengangkatan hakim agung sarat akan intervensi presiden dan kepentingan yang bersifat politis. Pandangan lain terkait persoalan pengangkatan hakim agung, disampaikan oleh Gregorius Seto Harianto dari fraksi Partai Demokrasi Kasih Bangsa (F-PDKB). Seto mengusulkan agar prosedur tata cara dan prosedur persyaratan mengangkat hakim agung perlu diperberat. Melalui cara tersebut diharapkan agar orangorang yang duduk di MA betul-betul bisa dipertanggungjawabkan secara etika dan moral. $^{8}$

Kemudian Sri Soemantri yang hadir dalam rapat dengar pendapat juga mengomentari relasi kekuasaan dalam

\footnotetext{
${ }^{7}$ Lihat, Risalah Perubahan UUDN RI Tahun 1945 (1999-2002) Tahun Sidang 1999, Jakarta: Sekertariat Jenderal MPR RI, 2008, hlm 58.

${ }^{8}$ Ibid, hlm 76.
} 
pemgangkatan hakim agung yang terjadi selama ini. Sri Soemantri menyatakan;

"Kekuasaan kehakiman di Indonesia mengalami kondisi yang sangat terpuruk. Semula itu hanya melanda pengadilan tingkat pertama dan tingkat tinggi, sekarang ini sudah merembet pada kekuasaan kehakiman yang paling tinggi. Oleh karena itu seleksi atau rekruitmen hakim agung menjadi penting guna memperoleh hakim agung yang kompeten dan berintegritas. ${ }^{9,}$

Melalui pendapatnya, Sri Soemantri mengkomparasikan proses pengangkatan hakim agung di India yang begitu ketat dan sangat menekankan pentingnya integritas. Bahkan untuk kepentingan tersebut, track record calon hakim agung harus diverifikasi ke fakultas perguruan tinggi tempat calon tersebut menempuh pendidikan.

Lebih lanjut Sri Soemantri menekankan pentingnya proses pengangkatan hakim agung yang bebas dari intervensi kekuasaan eksekutif. Sri Soemantri menyatakan;

"Di Indonesia sampai sekarang pemilihan hakim agung diajukan oleh DPR, yang tadinya untuk satu lowongan diajukan satu kursi, satu orang, sekarang ini agar tidak menyinggung perasaan Presiden, diajukan dua orang calon. Ini artinya memberikan kesempatan kepada Presiden untuk memilih calon yang kira-kira sesuai dengan keinginan Presiden itu sendiri. ${ }^{10}$

\footnotetext{
${ }^{9}$ Ibid, hlm 532.

${ }^{10}$ Ibid, hlm 533.
}

Pembahasan perubahan kedua UUD 1945 dilaksanakan mulai 6 Desember 1999 sampai Agustus 2000. Pada masa perubahan kedua ini, para anggota PAH I BP MPR kembali melanjutkan pembahasan tentang perubahan $\mathrm{BAB}$ kekuasaan kehakiman yang di dalamnya mengatur tentang relasi kekuasaan KY, DPR, dan Presiden dalam pengangkatan hakim agung.

I Dewa Gde Atmadja sebagai pakar yang hadir dalam pembahasan ini, menyatakan akan perlunya proses recruitment atau pengangkatan yang saling balancing dan transparan. ${ }^{11}$ Selain menyerap pendapat para pakar, PAH I juga mengundang jajaran Mahkamah Agung (MA) untuk menyatakan pendapat. Selaku wakil dari Mahkamah Agung (MA), Iskandar Kamil berpendapat agar Presiden tidak mengambil otoritas sebagai the last decision dalam pengangkatan hakim agung. Iskandar lebih menyetujui agar DPR yang memilih dan melakukan seleksi terhadap pengangkatan hakim agung, kemudian Presiden sebagai kepala negara berperan untuk melantik calon hakim yang telah di seleksi oleh DPR. ${ }^{12}$ Model relasi tersebut diyakini sebagai perwujudan checks and balances.

Oleh kemudian di masa perubahan kedua inilah pertama kali nomenklatur Komisi Yudisial (KY) hadir dimasa pembahasan melalui fraksi Golkar yang diwakili oleh Agun Gunandjar Sudarsa. ${ }^{13}$

\footnotetext{
11 Ibid, hlm 391.

12 Risalah Perubahan UUDN RI Tahun 1945 (19992002) Tahun Sidang 2000, Jakarta: Sekertariat Jenderal MPR RI, 2008, hlm 112.

${ }^{13}$ Naskah Komperhensif Perubahan UUDN Republik Indonesia Tahun 1945, Buku VI Kekuasaan Kehakiman; Perubahan UUD mengenai Komisi Yudisial, Jakarta, Sekertariat Jendral dan
} 
Lebih lanjut I Dewa Gede Palguna dari FPDIP mengusulkan pembentukan suatu badan yang mandiri, yaitu Komisi Yudisial pada tingkat nasional maupun daerah yang bertugas mengusulkan pengangkatan hakim. Palaguna menyatakan:

"untuk menghindarkan intervensi kekuasaan eksekutif terhadap para hakim, kami mengusulkan pembentukan suatu badan yang mandiri yang kami sebut Komisi Yudisial pada tingkat nasional maupun daerah, sehingga kalau dahulu Hakim Agung diangkat oleh Presiden dan hakim-hakim diangkat oleh Menteri Kehakiman, sekarang kami mengusulkan untuk Hakim Agung diangkat oleh Presiden, berdasarkan usul Komisi Yudisial Nasional. Dan untuk hakim biasa, maksudnya di luar Mahkamah Agung itu, diangkat oleh Presiden berdasarkan Komisi Yudisial Daerah. ${ }^{14}$

Pada pembahasan masa perubahan ketiga UUD 1945, proses pembahasan dilakukan jauh lebih matang dari pada masa perubahan-perubahan sebelumnya. Proses pembahasan dalam merumuskan relasi kekuasaan pengangkatan hakim agung mulai mendapatkan momentumnya. Soewarno dari fraksi PDI Perjuangan mengomentari rumusan Pasal 24B yaitu, hakim agung diangkat dan diberhentikan oleh Majelis Permusyawaratan Rakyat (MPR) atas usul Komisi Yudisial (KY) sebagai lembaga

Kepaniteraan Mahkamah Konstitusi RI, 2008, hlm 609.

14 Ibid, hlm 611. negara yang bersifat mandiri merupakan klausul yang tepat. ${ }^{15}$

Pendapat berbeda disampaikan oleh Zain Badjeber dari F-PPP, mempertanyakan relasi hakim agung yang diangkat oleh MPR. Mengingat status teoritik MPR yang masih diperdebatkan juga pada saat itu. Zain mengusulkan agar sebaiknya hakim agung diangkat oleh DPR. Oleh karena DPR mempunyai fungsi kontrol yang dapat menindaklanjuti pencalonan atau usul dari Komisi Yudisial yang bersifat independen. ${ }^{16}$

Selanjutnya I Dewa Gede Palguna dari F-PDI Perjuangan sependapat dengan apa yang diusulkan oleh Zain Badjeber dari FPPP. Pengangkatan hakim agung selayaknya melalui DPR yang pengesahannya diresmikan secara administratif oleh Presiden berdasar atas usul Komisi Yudisial. Model relasi ini yang kemudian dianggap oleh F-PDI Perjuangan sebagai perwujudan mekanisme checks and balances. ${ }^{17}$

Untuk mempertegas pendapat tersebut, Jakob Tobing yang juga dari F-PDI Perjuangan mengelaborasi tentang pentingnya Komisi Yudisial dalam pengangkatan hakim agung. Jakob menyatakan Komisi Yudisial yang seharusnya mempunyai kewenangan untuk melakukan fit and proper test, agar proses seleksi dan pengangkatan hakim agung tidak lagi dilakukan dalam nuansa yang bersifat politik. $^{18}$

F-Partai Golkar yang disampaikan oleh Agun Gunandjar berpendapat bahwa rumusan tersebut harus menjamin bahwa

\footnotetext{
15 Risalah Perubahan UUDN RI Tahun 1945 (19992002) Tahun Sidang 2001, Buku ke-tiga, Jakarta; Sekertariat Jenderal MPR RI, 2008, hlm 283.

${ }^{16} \mathrm{Ibid}$, hlm 298.

${ }^{17}$ Ibid, hlm 325.

${ }^{18}$ Ibid, hlm 354.
} 
rekruitmen hakim agung harus benar-benar bebas dari kepentingan politik. Hakim agung diangkat dan diberhentikan atas persetujuan DPR atas usul Komisi Yudisial. Frase dengan persetujuan DPR, dimaksudkan agar DPR tidak perlu lagi melakukan fit and proper test, dalam artian DPR tidak lagi melakukan proses seleksi melainkan hanya memberikan persetujuan. ${ }^{19}$ Lebih lanjut Agun menyatakan perlunya memikirkakan model checks and balances dalam pengangkatan hakim agung yang melibatkan cabang kekuasaan negara lainnya seperti legislatif dan eksekutif. ${ }^{20}$

Sementara itu Harjono yang merupakan F-PDI Perjuangan sangat setuju jika kewenangan untuk mengesahkan hakim agung ada di tangan presiden. Terkait dengan adanya keterangan "mengesahkan" Asnawi Latif dari F-PDU menginginkan agar dengan adanya keterangan mengesahkan, perlu dirumuskan secara tepat agar presiden hanya bersifat mengesahkan. ${ }^{21}$ Pendapat Asnawi ini mencoba mencegah kembali masuknya praktik-praktik masa lalu agar pengangkatan hakim agung bebas dari intervensi presiden.

Hingga pada tanggal 8 November 2001 pembahasan dilakukan melalui rapat paripurna yang dipimpin Amien Rais. Beberapa hasil pembahasan yang disepakati khususnya terkait dengan pengangkatan hakim agung, telah disahkan menajadi naskah perubahan ketiga BAB IX Kekuasaan Kehakiman UUD 1945. Proses pembahasan yang panjang dalam menyusun model dan proses pengangkatan hakim agung mendapatkan porsinya melalui Pasal

\footnotetext{
${ }^{19}$ Ibid, hlm 556.

${ }^{20}$ Ibid, hlm 534.

${ }^{21}$ Ibid, hlm 542-543.
}

24A Ayat (3) yakni; "calon hakim agung diusulkan Komisi Yudisial kepada Dewan Perwakilan Rakyat untuk mendapatkan persetujuan dan selanjutnya ditetapkan sebagai hakim agung oleh Presiden." 22

\section{Integrasi Ke Level Undang-Undang}

Sebagai respon atas disahkannya amandemen konstitusi yang dibahas secara berantai ditahun 1999 sampai 2002, bangunan konstitusi mulai diintegrasikan dalam level undang-undang. Salah satunya mengenai pengangkatan hakim agung. Konstitusi pasca amandemen telah menyepakati Komisi Yudisial (KY), Dewan Perwakilan Rakyat (DPR), dan Presiden sebagai aktor dalam proses seleksi dan pengangkatan hakim agung. Ketiga lembaga negara tersebut mempunyai relasi kekuasaan yang bersifat gradasi atau berjenjang.

Bangunan sistem tersebut, menghendaki agar dalam proses pengangkatan hakim agung terdapat suatu mekanisme yang saling imbang dan saling kontrol (checks and balances). Masing-masing aktor berperan menjaga keseimbangan mulai dari proses seleksi sampai dengan pengangkatan hakim agung. Menyadari bahwa hakim agung yang baik lahir dari sistem yang baik, blueprint undang-undang Komisi Yudisial (KY) mulai dirumuskan untuk mengatur arah implementasi pengangkatan hakim agung.

Jika melihat dari blueprint undangundang Komisi Yudisial (KY), political will instrumen tersebut bertujuan untuk memetakan proses rekruitmen yang baik. Melalui proses rekruitmen berjenjang, diharapkan mampu menghasilkan hakim agung yang berkualitas. Kualitas hakim agung tersebut, diukur melalui kemampuan

\footnotetext{
${ }^{22}$ Lihat Pasal 24A Ayat (3) UUDN 1945.
} 
hukum material dan prosedural (skill), kinerja (performance), dan integritas (integrity). Melalui komposisi tersebut, partisipasi publik juga dibuka seluas-luasnya agar dapat memberikan informasi kepada Komisi Yudisial, terkait dengan bakal calon hakim yang bersangkutan. Proses rekruitmen pun yang dilakukan oleh Komisi Yudisial melalui fit and proper test, dilakukan secara transparan dan akuntabel.

Setelah Komisi Yudisial menetapkan calon hakim agung yang dinyatakan lolos seleksi, Komisi Yudisial mengajukan nama calon untuk dimintakan "persetujuan" kepada Dewan Perwakilan Rakyat (DPR). Makna "persetujuan" ini yang coba dimaknai dengan model rasio. Cikal bakal lahirnya model rasio dalam jenjang pengangkatan hakim agung, yakni muncul pertama kali dalam naskah akademik UU Komisi Yudisial (KY). Misalnya jumlah formasi yang dimintakan satu lowongan, maka Komisi Yudisial (KY) menyiapkan 3 calon kepada Dewan Perwakilan Rakyat (DPR). Jika tiga orang calon maka Komisi Yudisial setidaknya mengajukan enam nama. $^{23}$

Rasio 1;3 ini yang ingin diidealkan oleh para perumus dalam level undang-undang sebagai model relasi kekuasaan antara KYDPR dan Presiden dalam proses pengangkatan hakim agung. Dengan model rasio ini, memberi peran secara langsung kepada DPR untuk kembali menilai dan memilih hakim agung yang diajukan oleh Komisi Yudisial (KY), untuk ditetapkan Presiden sebagai hakim agung.

23 Naskah Akademik UU Komisi Yudisial dalam Risalah Komisi Yudisial RI, Cikal Bakal Kelembagaan dan Dinamika Kelembagaan, Jakarta: KYRI, 2013, hlm 145.
Komposisi rasio 1;3 ini pun, kemudian ibarat menjadi "bisu" dalam proses pembahasan undang-undang Komisi Yudisial (KY). Sebagian besar fraksi yang membahas dan menyusun undang-undang Komisi Yudisial cenderung lebih banyak memperdebatkan jangka waktu pengajuan calon, perpanjangan usia pensiun hakim agung, dan syarat penulisan karya ilmiah terhadap bakal calon. Jika mengamati proses pembahasan undang-undang Komisi Yudisial (KY), para legislator memahami bahwa arah implementasi kewenangan Komisi Yudisial (KY) dalam proses pengangkatan hakim agung, hanya sebatas mengusulkan. Sehingga oleh karena itulah model rasio ini tidak menjadi isu strategis dalam masa pembahasan.

Hal ini yang kemudian melanggengkan relasi kekuasaan antara KY-DPR dan Presiden, sebagai relasi kekuasaan yang "berbasis rasio". Model ini kemudian yang diadopsi sebagai praktik yang lazim dalam proses pengangkatan hakim agung. Maka tidak heran dalam undang-undang Mahkamah Agung menyatakan "bahwa calon hakim agung yang diusulkan oleh Komisi Yudisial (KY) dipilih oleh Dewan Perwakilan Rakyat (DPR)". ${ }^{24}$

Dari masing-masing fase pembahasan di atas, maka relasi antara KY-DPR dan Presiden dalam pengangkatan hakim agung, adalah relasi kekuasaan yang "berbasis model rasio". Implikasi dari relasi kekuasaan yang berbasis model rasio ini, menempatkan Dewan Perwakilan Rakyat (DPR) sebagai aktor utama dalam

\footnotetext{
${ }^{24}$ Lihat Pasal 8 Ayat (2) UU Nomor 5 Tahun 2004 Jo. UU Nomor 3 Tahun 2009 Tentang Mahkamah Agung. Kemudian lihat juga Pasal 18 Ayat (5) UU Nomor 22 Tahun 2004 Jo. UU Nomor 18 Tahun 2011 Tentang Komisi Yudisial.
} 
pengangkatan hakim agung. Dominasi DPR dalam menilai, menguji, dan memilih calon hakim agung, menempatkan porsinya sebagai pemegang utama "bandul kekuasaan" dalam relasi antara KY-DPR dan Presiden.

Jika menganalisis masing-masing fase pembahasan secara integralistik, maka dapat dikatakan telah terjadi pergeseran kekuasaan dalam pengangkatan hakim agung. Komisi Yudisial yang seharusnya memegang porsi utama terhadap proses pengangkatan hakim agung, justru bergeser ke Dewan Perwakilan Rakyat (DPR). Hal ini kemudian menjadi sangat ironi mengingat historical design dibentuknya Komisi Yudisial (KY) sebagai organ independen adalah untuk meminimalisir dominasi eksekutif dan parlemen dalam proses pengangkatan hakim agung.

Terdapat beberapa faktor pendorong yang menyebabkan bergesernya peran Komisi Yudisial (KY) ke parlemen (DPR) dalam proses pengangkatan hakim agung. Beberapa faktor pendorong tersebut sbb:

a) Konstitusi "By Accident"

Proses amandemen konstitusi yang terjadi secara by accident, turut memengaruhi bergesernya peran Komisi Yudisial (KY) ke Dewan Perwakilan Rakyat (DPR) dalam pengangkatan hakim agung. Proses amandemen konstitusi yang terjadi secara berantai dengan metode tambal sulam, tidak mempunyai cetak biru (blue print) yang jelas. Ketiadaan cetak biru terhadap lembaga negara independen membawa sengkarut permasalahan khususnya terkait dengan pola relasi kekuasaan dengan organ konstitusi lainnya. Hal inilah yang kemudian berimbas pada Komisi Yudisial (KY).

"Kelatahan" itupun terlihat pada posisi teoritik Komisi Yudisial (KY) sebagai lembaga negara independen yang mendapatkan porsinya sebagai constitutional body pada level konstitusi. Cukup menyulitkan jika melihat bangunan konstitusi tidak secara tegas mengakui eksistensi lembaga negara independen sebagai salah satu cabang kekuasaan baru. Lebih dari itu dalam teori ketatanegaraan prinsip saling imbang dan saling kontrol (checks and balances) hanya dapat diterapkan dalam hubungan organ yang setara. Tidak heran jikan Komisi Yudisial sering di "anak tirikan" sebagai organ konstitusi ketika membangun relasi dengan cabang kekuasaan lain.

Oleh kemudian inilah yang terjadi dalam hal relasi kekuasaannya dengan Dewan Perwakilan Rakyat (DPR) dan Presiden dalam pengangkatan hakim agung. Peran Komisi Yudisial (KY) dalam pengangkatan hakim agung menjadi sebuah negasi ketika berhadapan dengan Dewan Perwakilan Rakyat (DPR) yang secara teoritik kelembagaanya telah begitu mengakar dan berpola.

b) Imbas Gelombang Besar Reformasi;

Gelombang besar reformasi telah membawa perubahan yang mendasar terhadap bangunan ketatanegaraan Indonesia. Arus besar reformasi 
tersebut mengakhiri dominasi kekuasaan Presiden (executive heavy) terhadap masing-masing poros kekuasaan. Ketika konfigurasi politik bergeser dari yang dahulunya bersifat otoritarian, kemudian bergerak ke arah yang lebih demokratis, justru menyebabkan poros kekuasaan kembali menjadi berat sebelah.

Dengan dalih mewujudkan konfigurasi politik yang demokratis, tanpa disadari pendulum kekuasaan telah berayun terlalu jauh terhadap kekuasaan legislatif. Inilah yang menyebabkan Dewan Perwakilan Rakyat (DPR) kerap mendapatkan porsi yang lebih besar dibanding cabang kekuasaan lain. Misalnya antara lain; (1) Model legislasi parlementer di era presidensial; (2) Kewenangan badan anggaran DPR yang berhak menentukan kegiatan dan jenis belanja masing-masing kementerian; (3) Kewenangan DPR dalam menentukan komposisi pimpinan lembaga negara. Oleh kemudian dalam hal pengangkatan hakim agung pun, juga mendapatkan pengaruh di bawah otoritas Dewan Perwakilan Rakyat (DPR) melalui bangunan relasi kekuasaan yang berbasis model rasio.

c) Mengawetkan kembali Model Klasik;

Dengan menempatkan Dewan Perwakilan Rakyat sebagai poros utama dalam pengangkatan hakim agung, pada dasarnya telah mengawetkan kembali praktik model klasik. Sebagaimana diketahui pola pengangkatan hakim agung yang melibatkan parlemen atau lembaga politik sudah mulai ditinggalkan oleh banyak negara. Alasan utama meninggalkan model ini pada dasarnya untuk menghindari intervensi pemilihan hakim agung dari tangan-tangan politik.

Namun demikian berbeda dengan negara Indonesia, alasan utama mempertahankan model klasik ini salah satunya adalah Dewan Perwakilan Rakyat (DPR) masih diyakini hadir sebagai jawaban representasi rakyat dalam pemilihan hakim agung. Terlebih pasca amandemen paradigma yang lahir cenderung menempatkan Komisi Yudisial (KY) sebagai supporting element dalam pengangkatan hakim agung yang fungsinya hanya sebatas mengusulkan. Momentum inilah yang kembali menguatkan posisi tawar Dewan Perwakilan Rakyat (DPR) sebagai aktor utama dalam pengangkatan hakim agung.

Ketiga faktor tersebutlah yang menjadi dasar bergesernya bandul kekuasaan antara KY-DPR dan Presiden dalam pengangkatan hakim agung. Hal tersebut mengakibatkan peran Komisi Yudisial (KY) bergeser ke Dewan Perwakilan Rakyat (DPR) untuk menguji dan memilih calon hakim agung, untuk ditetapkan oleh Presiden.

\section{Implikasi Putusan MK: Relasi Kekuasaan KY-DPR dan PRESIDEN}

Hampir satu dekade relasi kekuasaan berbasis "model rasio" antara KY-DPR dan 
Presiden menjadi praktik yang dilazimkan ketetanegaraan kita dalam pengangkatan hakim agung. Di penghujung tahun 2013 lonceng keras Mahkamah Konstitusi (MK) berdetak. Sebagai pengawal denyut konstitusi, Mahkamah Konstitusi (MK) mendalilkan putusan Nomor 27/PUU$\mathrm{XI} / 2013$ yang secara konstitusional merubah relasi kekuasaan antara KY-DPR dan Presiden. Implikasi putusan tersebut melahirkan beberapa konsekuensi logis terhadap relasi kekuasaan antara KY-DPR dan Presiden dalam pengangkatan hakim agung.

\section{Implikasi Yuridis}

\section{a) Inkonstitusionalitas Model Rasio}

Dengan adanya Putusan MK Nomor 27/PUU-XI/2013, Mahkamah Konstitusi telah menganulir beberapa pasal yang dinilai bertentangan dengan UUD 1945. Beberapa kalausul yang dibatalkan yaitu Pasal 8 Ayat (2), Ayat (3) dan Ayat (4) Undang-Undang Nomor 3 Tahun 2009 Tentang Mahkamah Agung, yang memuat nomenklatur "dipilih" oleh DPR. Frasa "3 (tiga) nama calon" yang diusulkan oleh Komisi Yudisial dalam Pasal 18 Ayat (4) UUD Nomor 18 Tahun 2011 Tentang Komisi Yudisial, juga dinyatakan bertentangan dengan UUD, sepanjang tidak dimaknai satu calon.

Dalam putusan tersebut, secara tegas Mahkamah Konstitusi (MK) membatalkan pola relasi kekuasaan yang berbasis rasio 1:3. Pola relasi demikian dianggap MK tidak mempunyai landasan konstitusional. Jika melihat risalah perdebatan UUD pada masa perubahan, tidak ada satupun historical design yang menempatkan relasi kekuasaan antara KY-DPR dan Presiden dengan model rasio. Kegagalan integrasi di level undang-undang telah membawa keterlibatan DPR dalam memilih calon hakim agung yang telah diusulkan oleh Komisi Yudisial.

Secara kasat mata sebenarnya nampak bahwa telah terdapat garis demarkasi antara klausul "pemilihan (dipilih) dan disetuji (persetujuan)". Dipilh dapat merujuk makna memilih calon dari nama yang ada, sementara disetuji lebih merujuk pada makna menyetujui atau tidaknya nama calon yang ada. Dengan demikian makna persetujuan DPR hanya dapat dimaknai sebagai bentuk menyatakan setuju atau tidak setuju (the right to confirm).

Keterlibatan DPR sebagai lembaga politik dalam pengangkatan hakim agung, bukanlah hal yang salah sepanjang dimaknai sebagai sebuah kerangka untuk membangun sistem saling imbang dan saling kontrol (checks and balances). Akan tetapi keterlibatan parlemen dapat menjadi sebuah mimpi buruk apabila parlemen diberi porsi kekuasaan yang dominan dalam proses pengangkatan hakim agung.

Memberi kesempatan parlemen (DPR) untuk menentukan pilihan dalam memilih hakim agung ibarat membuka kembali "nostalgia pahit" terhadap independensi peradilan. Sifat politis parlemen dapat membuka keran intervensi politik dalam menentukan hakim agung. Mempunyai latar belakang dan paham politik yang sama dengan calon hakim agung, dapat menjadi tolak ukur utama ketika parlemen diberi 
kewenangan untuk memilih hakim agung. Maka sandera politiklah yang kian menyelimuti independensi hakim tersebut dalam memutus perkara. M.Fajrul Falaakh menyatakan;

"dapat saja terjadi, seorang calon hakim agung yang memperoleh peringkat pertama dalam seleksi yang dilakukan Komisi Yudisial ternyata digugurkan dalam proses pemilihan di DPR. Digugurkannya calon hakim agung tersebut dapat karena diniliai bias dalam paandangan politik"25

Tesis yang diungkapkan oleh Fajrul Falaakh merupakan salah satu alasan kuat yang mendorong Mahkamah Konstitusi untuk mengurai kembali benang kusut yang terjadi pada relasi kekuasaan KY-DPR dan Presiden dalam pemilihan dan pengangkatan hakim agung. Terlebih pada prinsipnya amandemen konstitusi telah menyepakati bahwa alasan utama keterlibatan Komisi Yudisial dalam proses seleksi dan pengangkatan hakim agung, ialah untuk menjamin independensi kekuasaan yudikatif. Tidaklah membutuhkan waktu yang panjang untuk mewujudkan hal tersebut, jika proses pemilihan dan pengangkatan hakim agung benar-benar terbebas dari hasrat para "tangan-tangan politik".

\section{b) Negasi Fit and Propper Test DPR}

Ketika model relasi kekuasaan yang berbasis rasio telah dinyatakan inkonstitusional oleh Mahkamah Konstitusi, maka konsekuensi logis yang

\footnotetext{
${ }^{25}$ M.Fajrul Falaakh, Kompas, 17 Mei 2013, hlm 4.
}

muncul adalah mengingkari praktik fit and proper test DPR terhadap calon hakim agung yang diusulkan oleh Komisi Yudisial. Negasi ini secara otomatis timbul karena DPR hanya mempunyai fungsi untuk menyetujui atau tidak menyetujui (the right to confirm) calon yang diusulkan oleh Komisi Yudisial.

Beberapa faktor pendorong yang menegasikan fit and proper test DPR dalam seleksi dan pengangkatan hakim agung sebagai berikut;

1) DPR merupakan lembaga politik, maka segala bentuk pengujiannya sulit untuk terhindar oleh kepentingan politik.

2) Pada umumnya sebagian besar panitia yang melaksanakan uji kelayakan di DPR, tidak mempunyai latar belakang keilmuan, dan wawasan yang lebih baik dibandingkan dengan calon hakim agung. Oleh karena itu bisa saja terjadi hasil seleksi DPR justru tidak sesuai dengan kebutuhan Mahkamah Agung.

3) Minimnya metode pengukuran integritas dan kapabilitas di DPR terhadap calon hakim agung.

4) Dari praktik yang terjadi selama ini, banyak bakal calon tidak dihargai dan hanya menjadi ajang "perploncoan" di parlemen.

Dalam taraf level konstitusi pun, UUD tidak pernah memerintahakan agar DPR melakukan uji kelayakan dan kepatutan terhadap calon hakim agung. Uji kelayakan dan kepatutan atau yang 
biasa dikenal dengan istilah fit and proper test hanya menjadi otoritas Komisi Yudisial. Alasan utama DPR yang menyatakan bahwa uji kelayakan dan kepatutan merupakan representasi dari sistem checks and balances menjadi illogical.

Perlu dipahami bahwa konteks checks and balances tidak lah harus menjadi ajang supervisi DPR terhadap hasil seleksi Komisi Yudisial terhadap para calon hakim agung. Logika sederhana pun bisa dibangun, misalnya jika DPR mempunyai hak untuk melakukan supervisi dalam rangka checks and balances, maka dengan alasan yang sama, Presiden pun selaku pemangku puncak eksekutif juga mempunyai hak untuk melakukan supervisi terhadap hasil uji kelayakan di parlemen.

Namun dalam tataran praktis Presiden cukup mengesahkan dan melantik calon hakim agung terpilih untuk menjadi hakim agung. Dalam hal ini kedudukan Presiden dalam bangunan relasi kekuasaan antara KY-DPR dan Presiden hanya untuk melantik dan mengesahkan (the right to confirm). Demikian juga dengan DPR yang seharusnya hanya untuk menyetujui atau tidak menyetujui.

Konteks saling imbang dan saling kontrol terhadap relasi kekuasaan tersebut bukan dalam ranah supervisi hasil kerja masing-masing organ negara, tetapi dalam konteks melibatkan cabang kekuasaan lain. Desain relasi tersebut dibangun agar Komisi Yudisial mendapatkan porsi utama dalam menjaring calon hakim kemudian diusulkan ke DPR untuk dimintakan persetujuan, dan selanjutnya ditetapkan secara administratif oleh Presiden dalam bentuk pengangkatan. Model relasi tersebutlah yang menjadi politicall will dalam amandemen konstitusi kita, untuk kembali membangun tegaknya independensi peradilan.

\section{c) Purifikasi Kewenangan Komisi Yudisial}

Jika melihat pola perbandingan kewenangan Komisi Yudisial di pelbagai negara-negara lain, pada umumnya tidak ada satupun yang secara signifikan kewenanganya sama dengan Komisi Yudisial di Indonesia. Namun dapat ditarik satu garis "benang merah", bahwa karakteristik utama faktor pendorong kelahiran dan tujuan pelembagaan Komisi Yudisial di pelbagai negara, relatif sama.

Karakteristik Komisi Yudisial di pelbagai negara, yang umumnya disebut judicial council, merupakan instrumen trust recovery terhadap dunia peradilan. Organ Komisi Yudisial dibentuk secara khusus dan mandiri (independent regulatory agencies). Prancis, Italia, dan Belanda adalah model percontohan negara yang mengadopsi Komisi Yudisial sebagai organ negara yang mandiri. Faktor pendorong lahirnya Komisi Yudisial disebabkan oleh karena masuknya era demokratisasi baru di benua eropa. Ketika paham komunisme mulai bergeser ke era demokrasi, Komisi Yudisial hadir pada masa transisi tersebut.

Amandemen konstitusi telah menyapakati bahwa kewenangan Komisi 
Yudisial dalam Pasal 24B UUD, menjadi senjata ampuh dalam mencegah intervensi para penguasa terhadap dunia peradilan. Antara lain sebagai berikut;

a) Komisi Yudisial di dorong untuk menjadi "obat penawar" aroma politik dalam mekanisme pengangkatan hakim agung yang telah dianggap bias.

b) Komisi Yudisial di desain mewujudkan imparsialitas peradilan melalui sistem rekruitmen hakim agung.

c) Menjadi mitra utama publik dalam menganalisis rekam jejak bakal calon yang akan ditetapkan menjadi hakim agung.

d) Menjadi organ independen yang tidak tunduk di bawah pengaruh eksekutif, legislatif maupun yudikatif.

Meskipun cita-cita tersebut sempat gagal dan membisu dalam integrasi di level undang-undang, putusan Mahkamah Konstitusi berhasil melepas dominasi parlemen dalam mekanisme pengangkatan hakim agung. Hampir selama satu dekade kewenangan Komisi Yudisial tersandera dan hanya menjadi kosmetik politik di level undangundang, putusan tersebut hadir sebagai bentuk purifikasi atau pemurnian kewenangan Komisi Yudisial dalam ketatanegaraan RI. Perlahan tapi pasti, denyut konstitusi telah mengantarkan Komisi Yudisial untuk kembali pada marwah utamanya.

\section{Implikasi Politis}

\section{1) Aroma Arogansi Kelembagaan}

Ketika Mahkamah Konstitusi berhasil mengurai benang kusut terhadap relasi kekuasaan antara KY-DPR dan Presiden dalam menkanisme pengangkatan hakim agung, ada konsekuensi politis yang menyelimuti. Aroma arogansi kelembagaan justru menguat pasca putusan MK. DPR yang menjadi representasi untuk memberikan persetujuan kembali memainkan perannya. Tanpa parameter yang jelas DPR menggunakan hak nya untuk menolak seluruh calon hakim agung yang diusulkan oleh Komisi Yudisial.

Meskipun sulit dipercaya, aroma arogansi kelembagaan ini menjadi dinamika baru dalam mekanisme pengangkatan hakim agung. Hal ini bisa saja menjadi praktik yang berkelanjutan mengingat;

a) Gengsi kelembagaan DPR menjadi lebih menguat. Parlemen merasa hanya menjadi "tukang cap" atau hanya memberi legitimasi administratif terhadap Komisi Yudisial.

b) Minimnya rasa percaya "trust" DPR terhadap hasil screening bakal calon yang dilakukan oleh Komisi Yudisial.

c) Makna persetujuan DPR yang bersifat "right to confirm" secara konstitusioanal tetap dapat menolak dengan alasan "tidak mendapatkan persetujuan" selama tidak diartikan memilih.

d) Tidak ada bentuk parameter yang jelas oleh DPR untuk menggunakan haknya dalam menyatakan setuju 
atau tidak setuju terhadap calon hakim yang diusulkan oleh Komisi Yudisial.

Pola relasi kekuasaan antara KYDPR dan Presiden dalam pengangkatan hakim agung kembali harus tersandera oleh arogansi kelembagaan parlemen (DPR). Sifat kaku DPR menjadi evaluasi tersendiri dalam mekanisme pengangkatan hakim agung di Indonesia. Mahkamah Agung justru menjadi organ yang paling dirugikan akibat sifat kaku DPR. Produktivitas kinerja Mahkamah Agung pun menjadi tersandera jika DPR terus memperlihatkan arogansi kelembagaannya.

\section{2) Produktivitas Mahkamah Agung}

Produktivitas Mahkamah Agung menjadi pertaruhan. Itulah yang antara lain menjadi implikasi politis jika DPR tetap mempertahankan arogansi kelembagaannya untuk tidak memberikan persetujuan, terhadap calon hakim agung yang diusulkan oleh Komisi Yudisial. Kebutuhan mendesak Mahkamah Agung terhadap formasi hakim agung yang dibutuhkan harus tertunda akibat sikap kaku para anggota DPR.

Dalam hal ini beberapa imbas yang dapat terjadi dengan sikap penolakan DPR adalah sebagai berikut:

a) Penumpukan perkara di Mahkamah Agung

b) Kualitas kinerja juga semakin terganggu jika semakin banyak hakim agung yang memasuki usia pensiun. c) Ketika kinerja mulai terganggu maka substansi keadilan dalam putusan hakim juga menjadi pertaruhan.

d) Menurunya produktivitas Mahkamah Agung juga berimbas pada public distrust para justice seeker.

Ke empat hal tersebut tentut membuat akuntabilitas institusional Mahkamah Agung menjadi menurun. Akuntabilitas Mahkamah Agung dapat diukur ketika Mahkamah Agung mampu mengabdi kepada masyarakat yang haus akan keadilan. Ketika posisi-posisi hakim agung kosong akibat pola seleksi pengangkatan calon hakim yang buntu di parlemen, maka ke mana lagi para justice seeker harus mencari keadilan?.

\section{3) In-efisiensi Anggaran}

Bukan hanya berimplikasi pada produktivitas kinerja Mahkamah Agung, sifat arogansi kelembagaan DPR dapat berimbas pada pemborosan anggaran. Bayangkan ketika DPR terus menolak calon hakim yang diusulkan oleh Komisi Yudisial tanpa parameter yang jelas. Sebagian besar anggaran tersedot untuk melakukan seleksi dan uji kelayakan secara berulang-ulang, tanpa adanya indikator yang jelas DPR terhadap bakal calon dengan kriteria yang diinginkan.

Mekanisme seleksi yang dilakukan oleh Komisi Yudisial untuk menguji calon hakim agung, dapat menelan biaya hingga miliyaran rupiah. Mengingat metode screening Komisi Yudisial terhadap bakal calon harus melewati gradasi yang cukup panjang ditambah dengan analisis rekap rekam jejak masing-masing bakal calon. Relasi 
kekuasaan demikian pun menjadi tidak efisien dari aspek penggunaan anggaran.

Terdapat beberapa pembenahan ke depan untuk membangun sistem saling imbang dan saling kotrol terhadap relasi kekuasaan antara KY-DPR dan Presiden, dalam pengangkatan hakim agung. Beberapa pembenahan tersebut sebagai berikut:

a. Membangun corporate culture; corporate culture merupakan hal yang paling esensial dalam membangun relasi kekuasaan antara KY-DPR dan Presiden dalam pengangkatan hakim agung. Pasca amandemen memperlihatkan bahwa organ-organ negara baru yang lahir dimasa transisi demokrasi cenderung tidak mudah membangun satu bentuk kesepahaman dengan organ negara lama yang secara kelembagaan telah begitu kuat dan berpola. Hal ini pula yang menimpa Komisi Yudisial. Perannya kerap dinegasikan apabila berhubungan dengan organ-organ utama konstitusi lainnya. Corporate culuture dapat diaktualisasikan melalui kesepahaman dalam menyusun dan menyepakati kriteria hakim agung secara bersama antara KY-DPR dan Presiden.

b. Mengubah alur pengawasan DPR; Dewan Perwakilan Rakyat wajib mengubah alur pengawasan yang dipraktikan selama ini. Bentuk pengawasan tidak perlu dilakukan setelah Komisi Yudisial menentukan calon hakim yang akan diusulkan ke parlemen. Melainkan DPR harus mengawal sejak dini proses uji kelayakan dan kepatutan yang dilakukan oleh Komisi Yudisial terhadap bakal calon. Sehingga ketika diusulkan untuk menjadi calon hakim agung, DPR tinggal menyetujui calon hakim tersebut dan selanjutnya ditetapkan oleh Presiden menjadi hakim agung. Dengan model seperti ini, prinsip checks and balances dapat berjalan lebih efektif dan efisien.

c. Checks and Balances berbasis "Trust"; Ketika kedua poin di atas dapat terealisasi dengan baik, maka prinsip saling imbang dan saling kontrol (checks and balances) dapat berbasis trust. Sikap saling percaya antara masing-masing organ yang terlibat dalam relasi kekuasaan pengangkatan hakim agung, merupakan kunci sukses dalam mekanisme pengangkatan hakim agung. Arogansi kelembagaan dapat diminimalisir agar tidak terjadi negasi terhadap organ yang terlibat dalam relasi kekuasaan tersebut.

Beberapa gagasan penyempurnaan di atas menjadi modal utama dalam membangun mekanisme pengangkatan hakim agung. Dengan demikian tidak ditemukan lagi sikap apologi masing-masing organ yang terlibat dalam relasi kekuasaan pengangkatan hakim agung. Oleh karena itu menjadi pemebenaran ketika Odette Buitendam menyatakan tesisnya bahwa hakim agung yang baik hanya dapat lahir melalui sistem yang baik. -“Good Judges Are Not Born but Made". 


\section{PENUTUP}

Pada dasarnya relasi kekuasaan KY DPR dan Presiden ini didesain untuk membuat prinsip saling imbang dan saling kontrol terhadap masing-masing cabang kekuasaan dalam mekanisme pengangkatan hakim agung. Ekspektasi tersebut tidak berbanding lurus ketika diintegrasikan dalam level undang-undang. Pergeseran paradigma pun terjadi ketika DPR kembali mengambil alih aktor utama dalam pengangkatan hakim agung dan menegasikan peran Komisi Yudisial dengan relasi kekuasaan yang berbasis rasio. Pergeseran paradigma ini terjadi akibat sifat perubahan konstitusi yang bersifat by accident, imbas gelombang besar reformasi dan upaya untuk mengawetkan kembali model klasik.

Pasca putusan Mahkamah Konstitusi Nomor 27/PUU-XI/2013, terdapat konsekuensi logis terhadap relasi kekuasaan antara KY-DPR dan Presiden dalam mekanisme pengangkatan hakim agung. Dalih sembilan hakim konstitusi membawa implikasi yuridis dan politis terhadap relasi kekuasaan KY-DPR dan Presiden. Secara yuridis berimplikasi pada inkonstitusionalitas relasi kekuasaan yang berbasis rasio, pengingkaran terhadap fit and proper test DPR dan purifikasi kewenangan Komisi Yudisial. Secara politis berimplikasi pada arogansi kelembagaan DPR, produktivitas MA, dan in-efisiensi anggaran. Beberapa gagasan penyempurnaan pun tetap perlu dilakukan mulai dari membangun corporate culture, mengubah alur pengawasan DPR, dan sikap saling percaya antar organ yang terlibat dalam relasi kekuasaan pengangkatan hakim agung. Gagasan penyempurnaan tersebut agar inkonstitusionalitas relasi kekuasaan yang "berbasis rasio" dapat bertransformasi menjadi relasi kekuasaan yang "berbasis trust".

\section{DAFTAR PUSTAKA}

\section{Buku dan karya Ilmiah}

Ahmad Mujahidin, Peradilan Satu Atap di Indonesia, Refika Aditama, 2007.

Eric Barendt, an Introduction to Constitutional Law, New York: Oxford University Press, 1998.

Black Henry Campbell, Blacks Dictionary, St.Paul, Minnesota: West Publishing, 1991.

Christoper E Smith, Critical Judicial Nominations and Political Change, the Impact of Clerence Thomas, Westpoint: Preager Publisher: 1993.

Denny Indrayana, Negara antara Ada dan Tiada; Reformasi Hukum Ketatanegaraan, Jakarta: Kompas, 2008.

E.C.S. Wade \& G.Godfrey Phillips, Constitutional Law, Printed in Great Britain; London: Spottiswoode, Ballantyne \& Co.Ltd, 1960.

Fuady, Munir, Teori Negara Hukum Modern, Bandung: Refika Aditama, 2009.

F. Wiliam. Funk, \& Richard Seamon, Administrative Law; Examples \& Explanation, Aspen Law \& 
Business, Printed in the United States of America, New York, 2000.

Garoupa, Nuno dan Tom Ginsburg, "Guarding the Guardians: Judicail Councils and Judicial Independence", John M. Olin Law and Economic Working Paper No. 444, Public Law and Legal Theory Working Paper No. 250, Chicago, 2008.

Hamdan Zoelva, Pemakzulan Presiden di Indonesia, Jakarta: Sinar Grafika, 2011.

Herbert Jacob, Law and Politics in Comparative Perspective, Schraton: Chandler Publishing Company, 1971.

Johan Djohansjah, Reformasi Mahkamah Agung Menuju Independensi Kekuasaan Kehakiman, Jakarta: Kesaint Blanc, 2008.

Jimly Assihiddiqie, Perkembangan dan Konsolidasi Lembaga Negara Pasca Reformasi, Jakarta: Sinar Grafika, 2010.

Mahmud, Peter Marzuki, Penelitian Hukum, Jakarta: Kencana Prenada, Media Group, 2005.

Maria Soemardjono, Pedoman Pembuatan Usulan Penelitian; Sebuah Panduan Dasar, Jakarta: Gramedia Pustaka Utama, 1996.

Metodologi Penelitian

Ilmu Hukum (Bahan Kuliah), Yogyakarta: UGM, 2007.
Mauro Cappeleti, "Who watches the watchmen? A comparative Study on Judicial Responsibility", 31th The American Journal of Comparative Law, 1983.

Christoper M Larkins, "Judicial Independence and Democratization; A Theoritical and Conceptual Analysys", The American Journal of Comparative Law 4, Vol XLIV, 1996.

Montesquieu, The Spirit of Laws, University of California Press, Buku 1; Hukum secara Umum, diterjemahkan di Bandung: Nusamedia, 1977.

Naskah Komperhensif, Perubahan UUDN Republik Indonesia Tahun 1945, 2008, Buku VI Kekuasaan Kehakiman; Perubahan UUD mengenai Komisi Yudisial, Sekertariat Jendral dan Kepaniteraan Mahkamah Konstitusi RI, Jakarta.

Oce Madril, Perbandingan Komisi Yudisial Di Asia, dalam buku Bunga Rampai Komisi Yudisial "Membumikan Tekad Menuju Peradilan Bersih", Jakarta, 2011.

Penelitian PUSaKO Andalas, "Perkembangan Pengujian Perundang-undangan di Mahkamah Konstitusi”, Penelitian Pusat Studi Konstitusi Andalas-Kerja sama PUSaKO \& MKRI, 2010. 
Richardson Kridty, "A Definition of Judicial Independence", the University of New England Law Journal, 2005.

Risalah Komisi Yudisial RI, 2013, Cikal Bakal Kelembagaan dan Dinamika Kelembagaan, KYRI, Jakarta.

Risalah Perubahan UUDN RI Tahun 1945 (1999-2002) Tahun Sidang 1999, (2008), Buku pertama, Sekertariat Jenderal MPR RI, 2008, Jakarta.

Risalah Perubahan UUDN RI Tahun 1945 (1999-2002) Tahun Sidang 2000, (2008), Buku ke-dua, Sekertariat Jenderal MPR RI, 2008, Jakarta.

Risalah Perubahan UUDN RI Tahun 1945 (1999-2002) Tahun Sidang 2001, (2008), Buku ke-tiga, Sekertariat Jenderal MPR RI, 2008, Jakarta.

Rusli Muhammad, Kemandirian Pengadilan Indonesia, Yogyakarta: Uii Press, 2010.

Saldi Isra, Pergeseran Fungsi Legislasi; Menguatnya Model Legislasi Parlementer dalam Sistem Presidensial Indonesia, Jakarta: Rajawali Pers, 2010.

Sebastian Pompe, Runtuhnya Institusi Mahkamah Agung, Jakarta: Lembaga Kajian dan Advokasi Untuk Independensi Peradilan, 2012.

Seno, Oemar Adji dan Indriyanto Seno Adji, Peradilan Bebas\& Contempt of Court, Jakarta: Diadit Media, 2007.
S.Donald, Lutz, Principles of Constitutional Design, New York: Cambridge University Press, 2006.

Soerjono Soekanto, Pengantar Penelitian Hukum, Jakarta: UI Press, 2010.

Zainal Arifin Mochtar, Perihal Penataan Lembaga Negara, Bahan Kuliah Sistem Pengendalian Nasional, Yogyakarta: UGM Yogyakarta, April 2012.

\section{Peraturan Per-Undang-Undangan}

Undang-Undang Dasar Negara Republik Indonesia Tahun 1945.

Undang-Undang Nomor 22 Tahun 2004 Tentang Komisi Yudisial, Lembaran Negara Republik Indonesia Tahun 2004, Tambahan Lembaran Negara RI Nomor 4415.

Undang-Undang Nomor 5 Tahun 2004 Tentang Perubahan pertama Mahkamah Agung, Lembaran Negara Republik Indonesia Tahun 2004, Tambahan Lembaran Negara RI Nomor 9.

Undang-Undang Nomor 3 Tahun 2009 Tentang Perubahan kedua Mahkamah Agung, Lembaran Negara Republik Indonesia Tahun 2009, Tambahan Lembaran Negara RI Nomor 3.

Undang-Undang Nomor 48 Tahun 2009 Tentang Kekuasaan Kehakiman, Lembaran Negara Republik 
Indonesia Tahun 2009, Tambahan

Lembaran Negara RI Nomor, 157.

Undang-Undang Nomor 18 Tahun 2011

Tentang Perubahan Atas UndangUndang Nomor 22 Tahun 2004

Tentang Komisi Yudisial, Lembaran

Negara Republik Indonesia, Tahun

2011, Tambahan Lembaran Negara

RI Nomor, 106.

Putusan MK Nomor 27/PUU-XI/2013. 